\title{
Eurozone entry criteria after the crisis
}

\author{
Holger Wolf
}

Published online: 2 February 2012

(C) Springer-Verlag 2012

Eurozone entry is governed by the Maastricht convergence criteria on inflation, longterm interest rates, fiscal deficits, debt, exchange rate stability and legal regulations. ${ }^{1}$ The criteria, rooted in the economic realities of the early 1990s, have long been critically discussed, notably as the new and on average faster growing EU member states became eligible for Eurozone membership. To date, the difficulties of changing treaty-based rules have however stalled reforms. The crisis has further weakened belief in the ability of the criteria to fulfill their core function of effectively distinguishing between countries likely to thrive and countries likely to struggle under monetary union. The ability to satisfy the inflation criteria in a single year (often assisted by one time administrative intervention) has not prevented subsequent sustained divergences in unit labor cost growth across Eurozone members now posing adjustment challenges. Neither the fiscal criteria nor the long-term interest rate criteria have prevented the emergence of fiscal sustainability challenges, with a large majority of member states currently subject to the excessive deficit procedure.

Though much of the current debate on the future of the Eurozone centers on scenarios ranging from survival to various flavors of orderly or chaotic exits, all nonEurozone EU member states save Denmark and the United Kingdom are obligated to work towards the adoption of the single currency; and a number of non-Eurozone member states have recently affirmed their commitment towards a speedy entry. Expansion thus remains the default scenario. As non-members move towards application - most likely led by Lithuania - reconsidering entry criteria thus remains timely; equally important, the ongoing substantial changes in economic governance create a political window of opportunity whose absence has stymied earlier calls for reforms. The following note takes a short look at some of the issues arising in this context.

\footnotetext{
${ }^{1}$ Though countries applying for Eurozone membership are subject to a broader sustainability assessment by the ECB at the ERM-II stage as well as by the EC - in addition to the verification of their adherence to the formal Maastricht criteria to date applicants meeting the narrow Maastricht criteria have not been denied

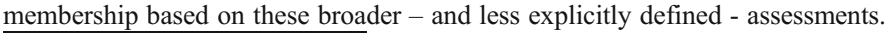

I thank Anne-Marie Gulde for insightful comments.

H. Wolf $(\bowtie)$

BMW Center for German and European Studies, Georgetown University, Washington, DC, USA

e-mail: wolfhc@georgetown.edu 


\section{Adding an OCA perspective}

The Maastricht criteria do not assess the degree to which an applicant fulfills optimal currency area (OCA) conditions. While the suitability of individual countries or country groups under OCA criteria was widely explored in the academic and policy literature in the 1990s and again as the new member states approached EU membership, ${ }^{2}$ it plays no formal role in decisions on Eurozone entry. Neither exposure to asymmetric shocks nor the ability of exchange rate movements to address such shocks nor the strength of alternative adjustment mechanisms - factor mobility, price and wage flexibility - capable of substituting for the devaluation option surrendered through Eurozone membership are included in the formal criteria.

Notwithstanding the endogeneity of the fulfillment of the criteria to the adoption of a single currency, ${ }^{3}$ the degree to which a potential member state meets OCA criteria retains informational value as the adjustment unfolds over an extended period. ${ }^{4}$ Notably, the commitment against using the devaluation option through Eurozone membership has not triggered sufficient adjustments in wage setting and labor market policies in some member states to prevent the recurrence of the significant cumulative unit labor cost deviations characterizing the pre-membership period, then addressed by periodic devaluations. In light of the - at best - slow adjustment, adding a formal assessment of pre-membership adherence to OCA criteria stands to improve the ability to assess the readiness of future Eurozone applicants to thrive under the single currency. ${ }^{5}$

\section{The Maastricht criteria ${ }^{6}$}

The Maastricht criteria can be assessed narrowly on whether they meet their stated objective of measuring current (and implicitly assuring continued) convergence, and more broadly on whether they effectively distinguish between countries likely to thrive or struggle under the single currency. On both metrics, significant doubts arise.

On the narrow level, the Maastricht convergence criteria increasingly require potential new member states to meet criteria not attained by many current member states. For the inflation criterion, the downward bias is structural, reflecting the inclusion of non-Eurozone members among the countries potentially defining the

\footnotetext{
${ }^{2}$ For a comprehensive review of issues relating to new member states, see Dabrowski (2005); the contributions in Susan Schadler (ed.), Euro Adoption in Central and Eastern Europe, IMF, Washington, DC and Darvas and Szapáry (2008), inter alia.

${ }^{3}$ See Frankel and Rose (1998) and specifically on the trade effect Rose (2000).

${ }^{4}$ See Rockoff (2000).

${ }^{5}$ In terms of feasibility, it is worth noting that the "five economic tests" devised by the previous UK government to assess the economic costs and benefits of Eurozone entry go some way towards an OCA assessment.

${ }^{6}$ The requirement to maintain stable exchange rates within the ERM II regime creates some challenges of its own - notably for countries on fixed rates experiencing significant productivity induced inflation in nontradables - but within the context of assessing the ability to surrender the devaluation option also provides a useful criterion. Views on the merits of the exchange rate criterion - not further discussed here - differ widely. See e.g. Buiter (2004) and the references in footnote 1.
} 
threshold and the continued use of three member states to define the threshold even as membership expands. ${ }^{7}$ For the fiscal criteria, the bias results trivially from the failure of a large majority of the current member states to meet the SGP thresholds. Beyond the bias towards requiring better performance of new compared to existing members, the Maastricht criteria have also been criticized for insufficiently taking into account the interdependence and the potential for clashes both between individual criteria $^{8}$ and between meeting the criteria and other objectives of macroeconomic policy. ${ }^{9}$

Some concerns with both criteria and the assessment process can be addressed through fairly contained adjustments within the existing framework. Beyond the criteria-specific issues discussed below, a number of authors have in particular raised concerns that the use of a single year of performance to assess the formal criteria invites the use of one-off administrative measures in preference to structural reforms, a concern that can in principle be readily addressed by extending the time-frame over which criteria have to be satisfied. ${ }^{10}$ Stepping outside the current framework, the crisis has refocused attention on the intrinsic suitability of the criteria to effectively identify countries likely to thrive under the common currency. The following paragraphs take up some of the issues in both regards.

\section{Fiscal criteria}

The constant $60 \%$ debt threshold set by the Maastricht Treaty has the advantages of clarity and (relatively) easy verification. ${ }^{11}$ It however does not provide a theoretically based metric for a sustainability threshold. As sustainability depends on country specific and time varying factors, including the future growth rate, theoretically based thresholds would likewise vary across member states and over time. As implemented, the threshold is excessively tight for countries with more favorable and too loose for countries with less favorable underlying trends. ${ }^{12}$

One reform option ${ }^{13}$ abandons the arbitrary common debt level limit in favor of a theory-based country and time specific threshold for (net) debt taking

\footnotetext{
${ }^{7}$ Gros (2004).

${ }^{8}$ See e.g. Buiter (2004, op.cit.), Gros (2004, op.cit.), Darvas and Szapáry (2008, op.cit.).

${ }^{9}$ See e.g. Lipinska (2008).

${ }^{10}$ See e.g. See Bulír and Hurník (2006), Darvas and Szapáry (2008, op.cit.) and Ahearne and Pisani-Ferry (2006).

${ }^{11}$ In addition to providing a reasonable margin of safety relative to the $90 \%$ threshold identified in recent research as associated with significant declines in economic performance. See Reinhart and Rogoff (2011).

${ }^{12}$ Outside the scope of this paper, the fiscal criterion also applies after membership through the stability and growth pact (SGP). The SGP has routinely failed to effectively restrain fiscal policy, reflected in the large majority of member states currently subject to the excessive deficit procedure. Current governance reforms aim to improve compliance with and thus credibility of the SGP through more tightly defined criteria, improved early assessment, and tougher enforcement. Against the dismal track record, the credibility of this latest reform is likely to be modest until the new rules have been market tested, a process now underway. The same applies to the national constitutional debt brakes already implemented or under consideration in several member states.

${ }^{13}$ A further issue beyond the scope of this paper are supplementary conditions focusing on procedural aspects of fiscal policy to address a range of challenges observed in some of the member states experiencing fiscal duress. Some of these issues are part of the current governance reforms. For an early assessment, see Buiti and Giudice (2002).
} 
account of starting positions, growth and real interest rate patterns. ${ }^{14}$ The economic ability to service debt however does not necessarily translate into the political ability and willingness to do so, creating the need for a further buffer. Formulated in a different context, the "fiscal space" approach identifying the gap between current debt levels and a threshold estimated based on past fiscal responses to debt changes provides one avenue. ${ }^{15}$ In the context of the Eurozone, a target level for the "fiscal space" provides an attractive criterion providing enhanced shorter-term fiscal policy flexibility. By construction, the closer adherence to theoretical conceptions of economic and political sustainability comes at the cost of introducing a higher degree of subjective assessment - a criterion based on ability to pay by definition depends on assumptions on future economic development, while the fiscal space concept faces the conceptual challenge that, notably in crisis, past political responses may not provide the best gauge for future responses. ${ }^{16}$ The quality and credibility of reformed fiscal targets would thus depend crucially on the robustness of the discussion regarding their definition and concrete implementation.

\section{Inflation criteria}

Like the fiscal criteria, the inflation threshold - a rate no more than one and a half percent above the average of the three lowest rates among EU member states - has attracted its share of criticism. For a number of reasons, the threshold is seen as excessively tight. Two of these are technical as discussed above. The inclusion of non-Eurozone members and the use of a constant number of countries to define the threshold even as EU membership expands tends to push the threshold towards the lower end of the range spanned by current Eurozone members. A third reason is fundamental: as the criterion does not differentiate between sources of inflation, it does not distinguish between inflation in the nontraded sector reflecting faster relative productivity growth in tradables (the Harrod-Balassa-Samuelson effect (HBS)) and general price level increases. If, as the evidence strongly suggests, ${ }^{17}$ the HBS effects are more significant in some non-Eurozone EU member states, adherence to the inflation criterion either requires unnecessarily restrictive policies creating a goal clash between productivity convergence and Eurozone membership or may lead to the adoption of one off administrative measures reducing the information value of the criterion.

Based on these concerns, a number of authors have argued for replacing the current inflation threshold with a new measure based on Eurozone inflation (potentially with a buffer to allow for HBS effects). ${ }^{18}$ The crisis has further

\footnotetext{
${ }^{14}$ See Buiter and Grafe (2004).

15 See Ostry et al. (2010).

16 Though the measure is by construction based on past policy responses, changes in fiscal responses will over time feed into a re-estimated threshold, the adjustment can be further augmented by attaching greater weight to recent fiscal responses in the estimation.

${ }^{17}$ For recent assessments of the HBS effect, see Égert (2007) and Mihaljek and Klau (2008).

${ }^{18}$ See e.g. Buiter and Grafe (2004, op.cit.), Gros (2004, op.cit.) and Darvas and Szapáry (2008, op.cit.). Alternatively, Buiter (2004, op.cit.) suggests a focus on tradables inflation.
} 
aggravated the problem as the reference value for inflation convergence is likely to be strongly influenced for the near future by the growing number of EU member states facing severe recession and deflationary pressures. ${ }^{19}$ Membership applicants may thus have to adopt contractionary policies to satisfy the criterion, while the temptation to resort to one-time administrative measures to meet the single year threshold noted in the literature will be amplified. Estonia was willing to pay the price when successfully applying for membership. It remains to be seen whether larger, less open and flexible economies are willing to do the same, in particular if the threshold were to come in substantially below the Eurozone average $^{20}$.

A more fundamental reform would replace the HICP inflation rate - which, in expected terms, makes a second entry as a component of the long-term interest rate by unit labor costs. Basing the entry criterion on a combination of the current (Euro) ULC level and the cumulative 5 year change (in Euro) relative to the Eurozone average directly allows for country specific HBS effects while shifting the focus to a core challenge facing several of the Eurozone crisis economies. ${ }^{21}$

\section{Interest rate criteria}

Similar to the inflation rate, the threshold - set as a two-point buffer above the average interest rate of the three member states with the lowest inflation rates - is subject to some technical challenges. During the period of limited intra-Eurozone sovereign risk premia dispersion preceding the fiscal crisis, the measure effectively captured differences in expected inflation as forward looking risk premia for applicants came down prior to actual membership. As expected inflation is endogenous to the likelihood of membership and thus the fulfillment of the other criteria, the independent information value of the forward looking long-term interest rate criteria was limited. ${ }^{22}$ Following the crisis, expected inflation differentials have been complemented by differences in risk premia, suggesting that the long term interest rate criteria may become a more valuable component of the assessment. Near term, the likely prevalence of high-interest rate crisis countries facing deflation among the member states defining the threshold will however substantially weaken the qualification hurdle. A shift from the current threshold to the median interest rate of all Eurozone member states would address the issue.

\footnotetext{
${ }^{19}$ In the last published convergence report (May 2010), the actual inflation average of the three top performers was in fact negative though the addition of the $1.5 \%$ buffer raised the threshold value just into positive territory.

${ }^{20}$ The issue can be addressed through the exclusion of member states judged to be subject to special inflation influences from the calculation, as has been done in the past with Lithuania (2004) and Ireland (2010).

${ }^{21}$ Consideration of the ULC levels can provide important additional insights. Thus while the increase in unit labor costs since 1998 in some crisis economies relative to Germany has been widely noted, a full assessment must take account of the fact that Germany commenced this period from high absolute ULC levels. The recent changes thus reflect to a significant extent a reversal of preceding losses in price competitiveness in Germany.

${ }^{22}$ See e.g. Gros (2004, op.cit.).
} 


\section{Conclusion}

The likelihood that a potential member state will thrive rather than struggle under a single currency depends on a variety of country characteristics. Conceptually, these divide into three groups. First, features influencing the likelihood that a country might benefit from nominal exchange rate variability - including the classic criterion of asymmetric shocks and the more recent issue of sustained changes in relative unit labor costs. Second, characteristics determining a country's ability to effectively utilize nominal exchange rate changes in such circumstances. Third, the development of alternative adjustment channels - notably wage and price flexibility and factor mobility - influencing the ability of a country to respond to shocks absent the option to devalue. Ideally, a full assessment of a candidate for monetary union membership would take account of the whole panoply of relevant factors.

Looking towards the future expansion of the Eurozone, a reformulation of the entry criteria accompanying the substantial economic governance reforms already passed or under consideration can contribute to identifying countries likely to encounter travails under monetary union and thus better advised to postpone membership and as relevant embark on additional reforms. A more explicit evaluation of applicant countries under OCA criteria, the replacement of fixed fiscal thresholds by a country and time varying fiscal space concept taking into account economic and political concepts of fiscal sustainability and closer attention to levels and cumulative longer term changes in relative unit labor costs are among options worth considering.

\section{References}

Ahearne A, Pisani-Ferry J (2006) The Euro: only for the agile, Bruegel Policy Brief 2006/01, Brussels Buiter W (2004) To purgatory and beyond, CEPR Discussion Paper No. 4342

Buiter W, Grafe C (2004) Patching up the pact. Econ Transit 12:67-102

Buiti M, Giudice G (2002) Maastricht's fiscal rules at ten: an assessment. J Common Market Stud 40 (5):823-48

Bulír A, Hurník J (2006) The Maastricht inflation criterion: how unpleasant is purgatory? IMF Working Paper No. 06/154, June

Dabrowski M (2005) A strategy for EMU enlargement, CASE Working Paper 290, Warsaw

Darvas Z, Szapáry G (2008) Euro area enlargement and Euro adoption strategies, European Economy Economic Papers No. 304, February

Égert B (2007) Real Convergence, price convergence and inflation differentials in Europe, CESifo Working Paper No. 2127

Frankel J, Rose A (1998) The endogeneity of the optimum currency area criteria. Econ J 108:1009-1025

Gros D (2004) The Maastricht criteria after enlargement: old rules for new members? Mimeo, University of Rome)

Lipinska A (2008) The Maastricht convergence criteria and optimal monetary policy for the EMU Accession Countries, European Central Bank Working Paper No. 896, May

Mihaljek D, Klau M (2008) Catching-up and inflation in transition economies: the Balassa-Samuelson effect revisited, BIS Working Paper No. 270, Basle

Ostry J, Ghosh A, Kim J, Qureshi M (2010) Fiscal space, IMF Staff Position Note No. 10/11, Washington

Reinhart C, Rogoff K (2011) A decade of debt, NBER Working Paper No. 16827

Rockoff H (2000) How long did it take the United States to become an optimal currency area? NBER Historical Working Paper No. 124

Rose A (2000) One market, one money: estimating the effect of common currencies on trade. Econ Pol 30:7-45 